\title{
Correction to: Ligninolytic enzyme involved in removal of high molecular weight polycyclic aromatic hydrocarbons by Fusarium strain $\mathrm{ZH}-\mathrm{H} 2$
}

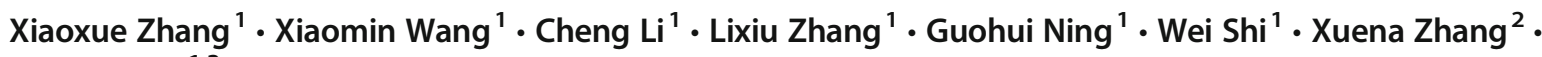 \\ Zhixin Yang ${ }^{1,3}$
}

Published online: 28 August 2020

(C) Springer-Verlag GmbH Germany, part of Springer Nature 2020

\section{Correction to: Environmental Science and Pollution Research https://doi.org/10.1007/s11356-020-10192-6}

The article Ligninolytic enzyme involved in removal of high molecular weight polycyclic aromatic hydrocarbons by Fusarium strain ZH-H2, written by Xiaoxue Zhang, Xiaomin Wang, Cheng Li, Lixiu Zhang, Guohui Ning, Wei Shi, Xuena Zhang and Zhixin Yang, was originally published electronically on the publisher's internet portal (currently SpringerLink) on 28 July 2020 with open access. With the author(s)' decision to step back from Open Choice, the copyright of the article changed on August 2020 to (C) SpringerVerlag GmbH Germany, part of Springer Nature 2020 and the article is forthwith distributed under the terms of copyright.

Publisher's note Springer Nature remains neutral with regard to jurisdictional claims in published maps and institutional affiliations.

The online version of the original article can be found at https://doi.org/ 10.1007/s11356-020-10192-6

\section{Xiaoxue Zhang}

yangzhixin@126.com

1 College of Resource and Environmental Sciences, Agricultural University of Hebei, 2596 Lekai South Street, Baoding 071000, People's Republic of China

2 TianJin Xiqing Economic-Technological Development Area, Tianjin 300385, People's Republic of China

3 Key Laboratory for Farmland Eco-Environment, Hebei Province, Agricultural University of Hebei, Baoding, People's Republic of China 